\title{
Cortical Inhibition Modified by Embryonic Neural Precursors Grafted into the Postnatal Brain
}

\author{
Manuel Alvarez-Dolado, ${ }^{1,4 *}$ Maria Elisa Calcagnotto, ${ }^{1 *}$ Kameel M. Karkar, ${ }^{3}$ Derek G. Southwell, ${ }^{1}$ \\ Dorothy M. Jones-Davis, ${ }^{1}$ Rosanne C. Estrada, ${ }^{1}$ John L. R. Rubenstein, ${ }^{2}$ Arturo Alvarez-Buylla, ${ }^{1}$ and Scott C. Baraban ${ }^{1}$ \\ Departments of ${ }^{1}$ Neurological Surgery, ${ }^{2}$ Psychiatry, and ${ }^{3}$ Neurology, University of California, San Francisco, San Francisco, California 94143 , \\ and ${ }^{4}$ Laboratorio de Regeneración Celular, Centro Investigación Príncipe Felipe, 46013 Valencia, Spain
}

\begin{abstract}
Embryonic medial ganglionic eminence (MGE) cells transplanted into the adult brain can disperse, migrate, and differentiate to neurons expressing GABA, the primary inhibitory neurotransmitter. It has been hypothesized that grafted MGE precursors could have important therapeutic applications increasing local inhibition, but there is no evidence that MGE cells can modify neural circuits when grafted into the postnatal brain. Here we demonstrate that MGE cells grafted into one location of the neonatal rodent brain migrate widely into cortex. Grafted MGE-derived cells differentiate into mature cortical interneurons; the majority of these new interneurons express GABA. Based on their morphology and expression of somatostatin, neuropeptide Y, parvalbumin, or calretinin, we infer that graft-derived cells integrate into local circuits and function as GABA-producing inhibitory cells. Whole-cell current-clamp recordings obtained from MGEderived cells indicate firing properties typical of mature interneurons. Moreover, patch-clamp recordings of IPSCs on pyramidal neurons in the host brain, 30 and $60 \mathrm{~d}$ after transplantation, indicated a significant increase in GABA-mediated synaptic inhibition in regions containing transplanted MGE cells. In contrast, synaptic excitation is not altered in the host brain. Grafted MGE cells, therefore, can be used to modify neural circuits and selectively increase local inhibition. These findings could have important implications for reparative cell therapies for brain disorders.
\end{abstract}

Key words: progenitor cells; GFP; electrophysiology; whole-cell recording; MGE; interneuron; GABA

\section{Introduction}

Cell transplantation may allow reconstitution of neural circuits in the diseased or injured brain (Bjorklund and Lindvall, 2000; Emsley et al., 2004; Winkler et al., 2005). To be successful, grafted cells should possess the ability to disperse through affected areas and differentiate into mature neurons expressing appropriate neurotransmitters or neuropeptides. Ideally, these cells should functionally integrate and directly influence circuitry in the damaged host brain. As such, the demonstration that transplanted neuronal precursors can migrate, differentiate, and form functional synaptic contacts is a critical first step in the development of cell-replacement therapies in the postnatal brain.

Most, if not all, inhibitory interneurons in the cerebral cortex originate from restricted regions of the ventral telencephalon known as the caudal ganglionic eminence and medial ganglionic eminence (MGE) (Nery et al., 2001; Marin and Rubenstein, 2001, 2003; Wichterle et al., 2001; Anderson et al., 2002; Butt et al.,

Received Aug. 9, 2005; revised May 31, 2006; accepted June 2, 2006.

This work was supported by National Institutes of Health Grant R01 NS048528-02. We thank Hynek Wichterle for his considerable effort and gracious support in establishing the graft protocol used in our studies. We also thank Simon J. B. Butt (in the Fishell laboratory) and Daniel L. Jones (in the Baraban laboratory) for assisting in the analysis of interneuron firing properties.

*M.A.-D. and M.E.C. contributed equally to this work.

Correspondence should be addressed to Scott C. Baraban, Department of Neurological Surgery, University of California, San Francisco, 533 Parnassus Avenue, Box 0520, San Francisco, CA 94143. E-mail: Scott.Baraban@ucsf.edu.

DOI:10.1523/JNEUROSCI.1540-06.2006

Copyright $\odot 2006$ Society for Neuroscience $\quad$ 0270-6474/06/267380-10\$15.00/0
2005; Wonders and Anderson, 2005). Immature inhibitory interneurons migrate widely in the embryonic brain, integrating into the circuitry of the developing striatum, cortex, and hippocampus. We demonstrated previously that MGE-derived cells transplanted into the adult brain differentiate into GABAergic interneurons, e.g., the main inhibitory cells of the cerebral cortex (Wichterle et al., 1999). In contrast to embryonic stem (ES) cellderived neurons (Wernig et al., 2004; Ruschenschmidt et al., 2005) and genetically engineered GABA-producing cells (Bosch et al., 2004; Thompson, 2005), transplanted MGE cells migrate long distances in the adult brain parenchyma and mature into neurons with morphologies resembling local interneurons (Wichterle et al., 1999; Butt et al., 2005). Based primarily on these observations, it has been suggested that MGE-derived cells may be used for brain repair and, in particular, could rescue deficits of brain inhibitory networks. A yet unresolved issue is whether transplanted MGE cells functionally integrate into the host neural circuitry and influence the overall level of inhibition.

To address these fundamental questions, we transplanted MGE cells from mice expressing green fluorescent protein (GFP) into the postnatal brain. We determined the time course of migration and differentiation of these neuronal precursors. We also analyzed the molecular phenotype of transplanted MGE precursors using antibodies directed against GABA, somatostatin (SOM), parvalbumin (PV), calretinin (CR), and neuropeptide $\mathrm{Y}$ (NPY). Using cortical slices from grafted animals, we show that MGE-GFP neurons exhibit intrinsic firing properties similar to 
fast-firing basket-type cortical interneurons. Electrophysiological measurements also demonstrate that MGE-derived neurons increase the overall level of GABA-mediated synaptic inhibition in grafted animals. This is the first report demonstrating that grafted neuronal precursors can modify levels of electrophysiological activity in the host brain by establishing functional inhibitory synapses with native neurons.

\section{Materials and Methods}

Tissue dissection and cell dissociation. Ventricular and subventricular layers from the anterior part of the medial ganglionic eminence, in which a sulcus clearly divides medial and lateral ganglionic eminences, were dissected from embryonic day 12.5 (E12.5) to E13.5 embryonic GFPpositive $\left(\mathrm{GFP}^{+}\right)$transgenic mice (Hadjantonakis et al., 1998). The day when the sperm plug was detected was considered E0.5. Bordering tissue between adjacent regions was discarded during dissection to avoid contamination. Tissue explants were mechanically dissociated by repeated pipetting through a $200 \mu$ l yellow plastic tip (10-20 times). Dissociated cells were washed with $1 \mathrm{ml}$ of L-15 medium containing DNase I (10-100 $\mu \mathrm{g} / \mathrm{ml})$ and pelleted by centrifugation $(2 \mathrm{~min}, 800 \times \mathrm{g}$ ). Cells were resuspended in $4-5 \mu \mathrm{l}$ of L-15 medium and kept on ice until additional use.

Transplantation. Highly concentrated cell suspension $\left(\sim 10^{6}\right.$ cells $/ \mu \mathrm{l}$ in $1 \mu \mathrm{l})$ was front-loaded into beveled glass micropipettes $(\sim 50 \mu \mathrm{m}$ diameter) that were prefilled with mineral oil and L-15 medium. Micropipettes were connected to a microinjector mounted on a stereotactic apparatus specially adapted for neonatal mice. Three- to 4-d-old CD-1 mice (Charles River Laboratories, Wilmington, MA) were anesthetized by exposure to $-4^{\circ} \mathrm{C}$ until pedal reflex was abolished. Anesthesia was maintained by performing surgery on a cold aluminum plate. A total of $5 \times 10^{4}$ cells per mouse in a $50-100 \mathrm{nl}$ volume were injected using a $45^{\circ}$ inclination angle and the following coordinates from bregma: striatum [3.3 mm anterior (A), $2.5 \mathrm{~mm}$ lateral (L), $2.6 \mathrm{~mm}$ dorsal (D)], cortex (2.2 $\mathrm{mm} \mathrm{A}, 3.5 \mathrm{~mm} \mathrm{~L}, 1.2 \mathrm{~mm} \mathrm{D}$ ), and hippocampus (1.2 $\mathrm{mm} \mathrm{A}, 1.7 \mathrm{~mm} \mathrm{~L}$, $2.0 \mathrm{~mm} \mathrm{D}$ ). For survival and migration distance estimations, $5 \times 10^{3}$ cells were grafted in a single point $(2.5 \mathrm{~mm} \mathrm{~A}, 3.0 \mathrm{~mm} \mathrm{~L}, 2.5-1.5 \mathrm{~mm} \mathrm{D})$. As a control, we injected an equivalent volume of heat-shocked "dead" cells. Grafted pups were returned to their mothers and analyzed after $3 \mathrm{~d}$, 1, 2, 3, and 4 weeks, and 3 months. All experimental animals were treated in accordance with University of California, San Francisco Laboratory Animal Research Center guidelines.

Immunostaining. Animals were transcardially perfused with $4 \%$ paraformaldehyde at different ages. Brains were removed, postfixed overnight in the same solution, and sectioned coronally $(50 \mu \mathrm{m})$ using a vibratome. Floating brain sections were immunostained with the following antibodies: rabbit anti-GABA (1:2500; Sigma, St. Louis, MO), mouse anti-parvalbumin (1:4000; Sigma), rabbit anti-calretinin (1:4000; Swant, Bellinzona, Switzerland), rat anti-somatostatin (1:500; Chemicon, Temecula, CA), rabbit anti-neuropeptide Y (1:5000; ImmunoStar, Hudson, WI), mouse anti-GFP (1:200; Qbiogene, Carlsbad, CA), chicken antiGFP (1:500; Chemicon), rabbit anti-Olig2 (1:20,000; a gift from D. Rowitch, Dana-Farber Cancer Institute, Boston, MA), rabbit anti-S100 $\beta$ (1: 1000; DakoCytomation, Carpinteria, CA), mouse anti- neuronalspecific nuclear protein NeuN (1:200; Chemicon), mouse anti-glial fibrillary acidic protein (1:1000; Chemicon), mouse anti-calcium calmodulin kinase $\alpha \mathrm{II}$ (1:100; Sigma), goat anti-choline acetyltransferase (ChAT) (1:100; Chemicon), and rabbit anti-tyrosine hydroxylase (TH) (1:1000; Chemicon). The following secondary antibodies were used: cyanine 3 (Cy3)-conjugated donkey anti-mouse, Cy3-conjugated donkey anti-rabbit, Cy2-conjugated donkey anti-mouse, and biotin-conjugated donkey anti-mouse (1:400; all from Jackson ImmunoResearch, West Grove, PA), and Alexa 488-conjugated goat anti-chicken, Alexa 594conjugated donkey anti-rabbit, and Alexa 594-conjugated donkey antimouse (1:500; all from Invitrogen, Carlsbad, CA). Sections were washed in PBS and blocked for $1 \mathrm{~h}$ in PBS containing 10\% donkey serum and $0.1 \%$ Triton X-100 at room temperature. Sections were then incubated overnight at $4^{\circ} \mathrm{C}$ in primary antibodies diluted in PBS containing $10 \%$ donkey serum and $0.1 \%$ Triton X-100, were then washed three times in PBS, and incubated with secondary antibodies for $1-2 \mathrm{~h}$ at room temper- ature in the dark. For GABA immunostaining, Triton X-100 was eliminated from the protocol. Biotinylated secondary antibodies and $\mathrm{ABC}$ kit (Vector Laboratories, Burlingame, CA) were used for peroxidase reaction with diaminobenzidine.

Cell counts and quantification. Quantifications of cell bodies stained with immunohistochemistry or GFP were counted on digitized images obtained with a DFC480 digital camera and IM500/FW4000 image manager software (Leica, Cambridge, UK) on a DM6000B microscope (Leica, Wetzlar, Germany). Survival percentage of grafted cells was estimated counting all GFP ${ }^{+}$cells in 10 coronal sections ( $300 \mu \mathrm{m}$ apart, one section with injection site, four forward to the injection, and five backward). A representation of cell number versus distance to injection site was obtained on graph paper. Quantification of area under the graph was estimated as total number of survived cells. Percentage of cell survival was estimated as $100 \times$ (number of survived cells)/(number of transplanted cells) $\left(5 \times 10^{4}\right)$.

The percentage of grafted $\mathrm{GFP}^{+}$cells expressing GABA, PV, CR, SOM, or NPY after transplantation was calculated in three coronal sections through each of the following regions: somatosensory cortex, striatum, and hippocampus. For somatosensory cortex, sections were separated by $500 \mu \mathrm{m}$ [bregma levels +0.50 and $-0.50 \mathrm{~mm}$ (defined by Paxinos and Franklin, 2001)]; a $1 \mathrm{~mm}$ strip from the white matter to the pial surface (covering an area between lateral coordinates 1.5 and $2.5 \mathrm{~mm}$ from the midline) was analyzed in each section. For striatum, sections were 400 $\mu \mathrm{m}$ apart (bregma levels +1.60 and $+0.80 \mathrm{~mm}$ ). For hippocampus, sections were $300 \mu \mathrm{m}$ apart (bregma levels -1.50 and $-2.10 \mathrm{~mm}$ ). At least $100 \mathrm{GFP}^{+}$cells $(\sim 50$ in cortical layers III-V and $\sim 50$ in layers $\mathrm{V}$-VI; visualized using $4^{\prime}, 6^{\prime}$-diamidino-2-phenylindole) were analyzed for each marker in each animal. Brains $(n=5)$ were analyzed at 1,3 , and 6 months after transplantation. Two observers blinded to condition were used for quantitative analysis. Results were presented as mean \pm SEM, and statistical analysis was performed using the Student's $t$ test.

For quantifications of neuronal bodies that were immunopositive for interneuron markers (GABA, PV, and SOM) in the somatosensory cortex of grafted and contralateral hemispheres, we transplanted $\sim 50,000$ MGE cells in the neocortex or an equivalent volume of heat-shocked dead cells as a control. Brains were analyzed $60 \mathrm{~d}$ after transplantation (DAT); three zones were established for quantification in the somatosensory cortex, as defined by Paxinos and Franklin (2001). The first zone covers a $100 \mu \mathrm{m}$ distance around the injection site. This enclosed a 0.24 $\mathrm{mm}^{3}$ volume delimited by a $200 \mu \mathrm{m}$ length $(100 \mu \mathrm{m}$ forward plus 100 $\mu \mathrm{m}$ backward from injection site) and a $1 \mathrm{~mm}$ strip in the somatosensory cortex covering an area between lateral coordinates 1.5 and $2.5 \mathrm{~mm}$ from the midline and the white matter to the pial surface (approximately an area of $1.2 \mathrm{~mm}^{3}$ ). Four coronal sections (50 and $100 \mu \mathrm{m}$ forward and backward from injection site) per mouse were analyzed. The second zone covers a distance between 100 and $600 \mu \mathrm{m}$ from injection site, enclosing a $1.2 \mathrm{~mm}^{3}$ volume. Six coronal sections $(150,300$, and $600 \mu \mathrm{m}$ forward and backward from injection site) were quantified. The last zone includes a distance between 600 and $1200 \mu \mathrm{m}$ from the injection site, enclosing a $1.44 \mathrm{~mm}^{3}$ volume. Six coronal sections $(650,800$, and $1200 \mu \mathrm{m}$ forward and backward from injection site) were analyzed. The three quantified zones were enclosed between the septum (bregma level $+0.8 \mathrm{~mm}$ ) and the dorsal hippocampus (bregma level $-1.4 \mathrm{~mm}$ ).

For GABA and PV quantifications, 500-600 cells were counted per animal in each hemisphere $(n=10)$. For SOM, 300-400 cells per animal in each hemisphere were counted $(n=10)$. To compare results between the grafted and contralateral hemispheres, statistical analysis using a onetail paired Student's $t$ test was applied and contralateral results were referred to as $100 \%$. Results are presented as mean \pm SEM. Significance level was taken as $p<0.05$.

Electrophysiology. Acute tissue slices were prepared from male or female CD-1 mice 2, 3, and 4 weeks after transplantation, as described previously (Calcagnotto et al., 2002). Whole-cell recordings were obtained from visually identified neurons (pyramidal cells and $\mathrm{GFP}^{+}$cells) using an infrared differential interference contrast (IR-DIC) video microscopy system and epifluorescence microscopy (Molecular Devices, Sunnyvale, CA). Intracellular patch pipette solution used for whole-cell voltage-clamp recordings to study IPSC contained the following (in $\mathrm{mm}$ ): 
120 Cs-gluconate, $10 \mathrm{HEPES}, 11$ EGTA, $11 \mathrm{CsCl}_{2}, 1 \mathrm{MgCl}_{2}, 1.25 \mathrm{QX}-314$ (lidocaine $\mathrm{N}$-ethyl bromide), $2 \mathrm{Na}_{2}$-ATP, and $0.5 \mathrm{Na}_{2}-\mathrm{GTP}$, pH 7.25 (285-290 mOsm). For EPSC, solution contained the following (in mM): $135 \mathrm{CsCl}_{2}, 10 \mathrm{NaCl}, 2 \mathrm{MgCl}_{2}, 10$ HEPES, 10 EGTA, $2 \mathrm{Na}_{2} \mathrm{ATP}, 0.2$ $\mathrm{Na}_{2} \mathrm{GTP}$, and 1.25 QX-314, adjusted to $\mathrm{pH} 7.2$ with $\mathrm{CsOH}$ (285-290 $\mathrm{mOsm}$ ). To isolate GABAergic currents, slices were perfused with normal artificial CSF (nACSF) containing $20 \mu \mathrm{M} 6$ 6-ciano-7-dinitroquinoxaline2,3-dione (CNQX) and $50 \mu \mathrm{M} \mathrm{D}-(-)$-2-amino-5-phosphonovaleric acid (D-APV), and IPSCs were recorded at a holding potential of $0 \mathrm{mV}$; for EPSCs, slices were perfused with nACSF containing $10 \mu \mathrm{m}$ bicuculline methiodide (BMI), and EPSCs were recorded at a holding potential of $-75 \mathrm{mV}$ unless otherwise noted. Miniature IPSCs were recorded in nACSF containing $1 \mu \mathrm{m}$ tetrodotoxin. IPSCs/EPSCs were recorded on "aged-matched" pyramidal neurons (MGE graft-derived or shamoperated) in either the same slice or a different one. Age-matched refers to slices obtained from mice within a $3 \mathrm{~d}$ time period. Evoked currents were elicited using a monopolar electrode placed in the white matter. Pyramidal cells were filled with Lucifer yellow and analyzed post hoc. To study the intrinsic firing properties of $\mathrm{GFP}^{+}$cells in current clamp, intracellular patch pipette solution contained the following (in $\mathrm{mM}$ ): 120 KMe-gluconate, $10 \mathrm{KCl}, 1 \mathrm{MgCl}_{2}, 0.025 \mathrm{CaCl}_{2}, 10 \mathrm{HEPES}, 0.2$ EGTA, 2 Mg-ATP, and 0.2 Na-GTP, pH 7.2 (285-290 mOsm). GFP ${ }^{+}$cells were depolarized and hyperpolarized via direct current injection (5-1000 ms duration). For analysis of firing properties and classification into neuronal subtypes, an investigator blind to the status of the recording evaluated current-clamp files for step depolarizations between 500 and $1000 \mathrm{~ms}$ in duration. Interneurons were classified as regular-spiking nonpyramidal (RSNP), fast spiking, or burst-onset RSNP (Butt et al., 2005). In some cases, cells were filled with Alexa red and monitored in real time. Voltage and current were recorded with an Axopatch 1D amplifier (Molecular Devices) and monitored with an oscilloscope and with pClamp 8.2 software (Molecular Devices), running on a Pentium personal computer (Dell Computer Company, Round Rock, TX). Whole-cell voltage-clamp data were low-pass filtered at $1 \mathrm{kHz}(-3 \mathrm{~dB}$, eight-pole Bessel), digitally sampled at $20 \mathrm{kHz}$. Whole-cell access resistance was carefully monitored throughout the recording, and cells were rejected if values changed by more than $25 \%$ (or exceeded $20 \mathrm{M} \Omega$ ); only recordings with stable series resistance of $<20 \mathrm{M} \Omega$ were used for analysis.

Whole-cell currents were analyzed using time-to-peak and time-todecay parameters in Mini Analysis 5.6.28 (Synaptosoft, Decatur, GA), e.g., a software program that detects and measures spontaneous events. Briefly, each event was manually selected based on the IPSC/EPSC waveform and rise time, amplitude, and decay properties. The time-to-peak was measured as a difference between the last point before a detected event and the event peak; amplitude was measured at the maximum peak. The threshold amplitude was calculated according to the baseline level. The time-to-decay was taken as the time from the peak to a point one-third of the peak value. Between 100 and 200 individual events were analyzed for each cell. Evoked IPSCs/EPSCs and intrinsic properties were analyzed using Clampfit 8.2 software (Molecular Devices). Kinetic analysis of events was performed with a single-exponential function. Results are presented as the mean \pm SEM. To compare results between different cell types, we used a one-way ANOVA with significance level of $p<0.05$.

\section{Results \\ Embryonic MGE cells grafted in juvenile brain rapidly disperse long distances}

Using embryonic brain slices (Anderson et al., 1997; Wichterle et al., 1999; Marin and Rubenstein, 2001), in utero fate mapping (Wichterle et al., 2001), and tissue coculture assay (Wichterle et al., 2003), we reported previously that neocortex is permissive for the migration and integration of transplanted MGE cells. To establish an efficient method for the transplantation and functional assessment of MGE progenitors in a host brain, the MGE was dissected from transgenic E12.5-E13.5 mice expressing GFP (Hadjantonakis et al., 1998). GFP expression was used to track the migration and differentiation of grafted cells in live or fixed tissue. After mechanical dissociation, $\mathrm{GFP}^{+}$MGE cells were

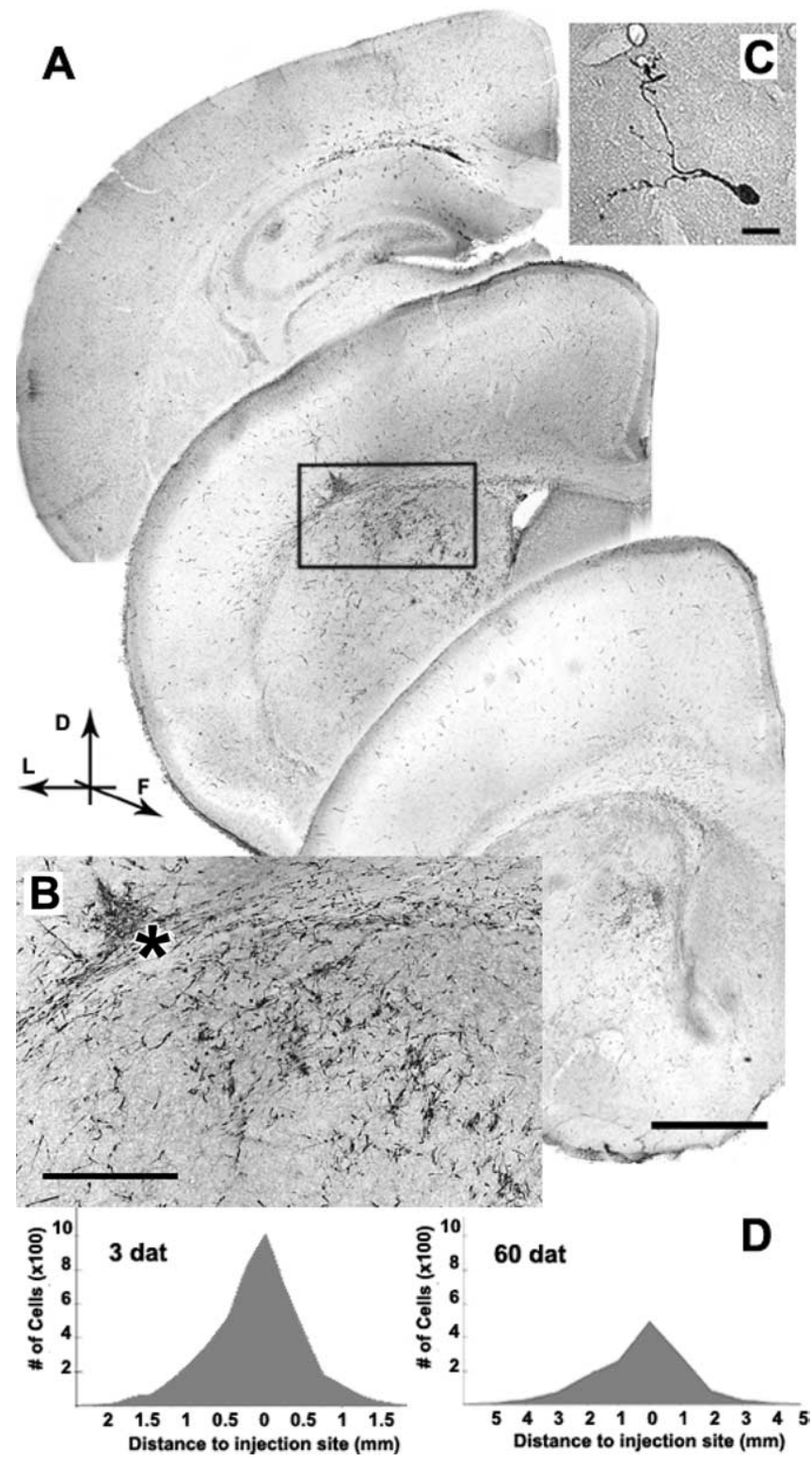

Figure 1. Distribution of MGE derived cells $3 \mathrm{~d}$ after transplantation into neocortex and striatum. A, MGE-derived cells were detected by immunohistochemistry against GFP. Serial sections were used to determine the position of labeled cells. Notice the wide distribution throughout neocortex, striatum, and hippocampus. $\boldsymbol{B}$, High magnification of area in $\boldsymbol{A}$ showing MGE cells moving away from injection site $\left({ }^{*}\right)$. C, Detail of a typical MGE migrating cell. $\boldsymbol{D}$, Distribution of grafted cells 3 and 60 DAT; number of cells/distance of serial sections. Scale bars: $A, 1 \mathrm{~mm} ; \boldsymbol{B}, 250 \mu \mathrm{m} ; \boldsymbol{C}, 25 \mu \mathrm{m}$. F, Frontal; D, dorsal; L, lateral.

loaded into a glass micropipette and grafted into the neocortex and dorsal striatum in the brain of postnatal day 3 or 4 mice (Lois and Alvarez-Buylla, 1994). Host animals were then killed at $3 \mathrm{~d}$ and $1,2,3$, and 4 weeks after grafting. Representative examples of the injection sites and postmigratory behaviors of $\mathrm{GFP}^{+}$cells are shown in Figures $1 A$ and $2 A$.

At 3 DAT, many $\mathrm{GFP}^{+}$cells had migrated away from the injection site (Fig. $1 B$ ) into most of the neocortex, striatum, and hippocampus (Fig. 1A). Survival rate of grafted cells at this time point was $38.9 \pm 7.3 \%(n=10)$, with approximately two-thirds of these cells positive for GABA $(64.7 \pm 3.7 \%)$. At 3 DAT, most $\mathrm{GFP}^{+}$cells had the typical morphology of tangentially migrating interneurons, with a small elongated cell 


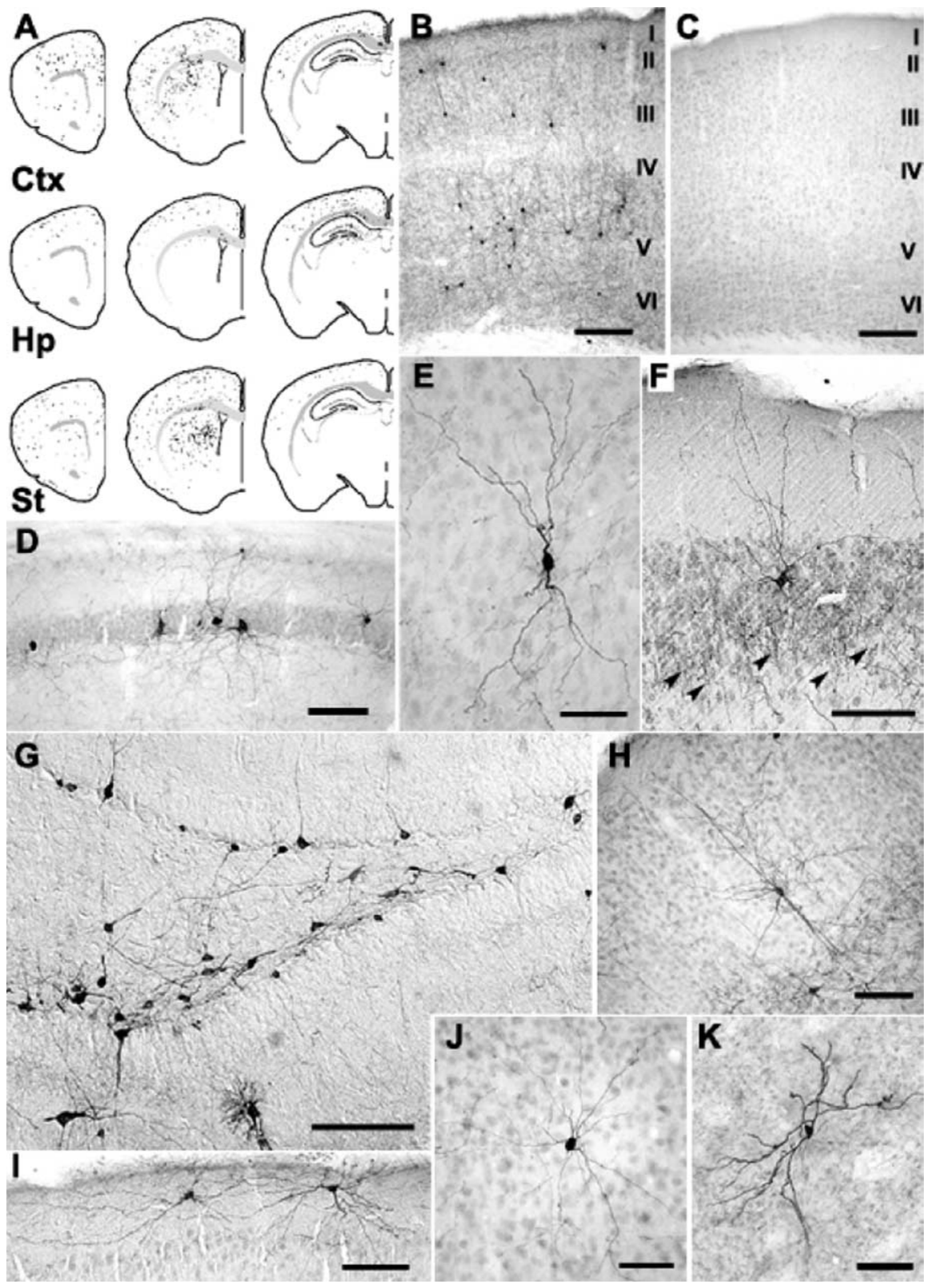

Figure 2. Acquisition and distribution of mature interneuron morphology at 60 DAT. A, Camera lucida maps indicating the position of MGE graft-derived cells at three rostrocaudal levels after transplantation into neocortex (Ctx), hippocampus (Hp), and striatum (St). $\boldsymbol{B}$, Detection of grafted cells by immunohistochemistry against GFP in the ipsilateral somatosensory cortex. Note the wide distribution of grafted cells in multiple cortical layers. Compare the dark background in layers I-II and V of the injected hemisphere $(\boldsymbol{B})$ versus the contralateral hemisphere $(\boldsymbol{C})$. $\boldsymbol{E}-\boldsymbol{K}, \mathrm{GFP}$ detection by immunohistochemistry provides a Golgi-like staining of grafted cells. MGE-derived cells in cortex differentiated into neurons presenting typical morphology of interneuron subtypes, e.g., bitufted or bipolar cells $(\boldsymbol{E})$, chandelier cells $(\boldsymbol{F})$ with synaptic boutons resembling candlesticks (arrowheads), basket cells $(\boldsymbol{H})$, neurons with small body $(\boldsymbol{I})$, and multipolar cells $(\boldsymbol{J})$. In hippocampus, grafted cells accumulated in $C A 1(\boldsymbol{D})$ and dentate gyrus $(\boldsymbol{G})$. In striatum, the vast majority of cells differentiated into medium aspiny interneuron ( $\boldsymbol{K})$. Scale bars: $\boldsymbol{B}-\boldsymbol{D}, \boldsymbol{F}, \boldsymbol{H}$, $I, 100 \mu \mathrm{m} ; \boldsymbol{E}, \mathbf{G}, J, K, 50 \mu \mathrm{m}$.

soma and a forked leading process (Fig. 1C). $\mathrm{GFP}^{+}$cells spread extensively around the injection site in all directions. This extraordinary migratory ability was noted previously in adults (Wichterle et al., 1999). However, in the young postnatal brain, the migration was more extensive and appears to be faster. Grafted cells covered a linear distance of $336 \pm 82 \mu \mathrm{m} / \mathrm{d}$ $(n=20)$, with a maximum of $525 \mu \mathrm{m} / \mathrm{d}$, analyzed 3 DAT; this speed of migration is greater than reported in adults $(\sim 120$ $\mu \mathrm{m} / \mathrm{d})$ and similar to that measured in vitro $(280 \mu \mathrm{m} / \mathrm{d}$ on matrigel) (Wichterle et al., 1999). A representation of cell number versus migration distances at 3 DAT results in a bell-shape curve (Fig. $1 D)$. These data suggest that cells did not have a strong preference for a particular migratory route and disperse in all directions from the injection site.

\section{Differentiation of grafted MGE cells in the host brain}

Analysis of grafted brains 7 DAT reveals a widespread distribution of $\mathrm{GFP}^{+}$ MGE cells. At 7 DAT, most grafted cells no longer exhibited a migratory morphology; instead, they had multiple processes, and some cells had a thin and longer axon-like process (data not shown). This indicates that initiation of differentiation of grafted MGE-derived neuronal precursors occurs between 3 and $7 \mathrm{~d}$ after transplantation.

Fourteen and 21 DAT, cells acquired progressively a more mature morphology, showing larger and more elaborated dendritic trees with longer axons. At 30 DAT, some $\mathrm{GFP}^{+}$cells were $>5 \mathrm{~mm}$ away from injection site; their distribution was similar to that found at 3 DAT (Fig. 1D). However, the survival percentage was reduced to $19.9 \pm 3.9 \%(n=10)$. A similar level of survival, $21.2 \pm 4.1 \%(n=10)$, was observed at $90 \mathrm{DAT}$. The morphology of the grafted cells was studied after GFP immunohistochemistry, which provides Golgilike staining. Two months after transplantation, $\mathrm{GFP}^{+}$cells had elaborate dendritic trees extending profusely through cortical layers (Fig. 2). Axons and their presynaptic terminals could also be visualized. Thus, grafted cells appeared to complete their differentiation into functionally integrated interneurons within 1 month after transplantation.

MGE-derived cells in the cortex differentiated into neurons with morphologies of at least five different interneuron subtypes, e.g., bitufted or bipolar cells, chandelier cells, basket cells, neurons with small body, and multipolar cells (Fig. 2). For instance, some neurons displayed synaptic buttons resembling arrays of candlesticks, suggesting that they differentiated into chandelier cells (Fig. $2 B, E, F, H, I, J$ ). In contrast, grafted cells in the striatum differentiate primarily to medium aspiny interneurons (Fig. $2 \mathrm{~K}$ ) and in the hippocampus to interneurons with morphologies typical for this region (basket, axo-axonic, and bistratified cells) (Fig. 2D,G). None of the MGE-derived neurons exhibited morphological features of cortical pyramidal neurons, e.g., triangular cell soma extending a thick spiny apical dendrite. Some immature oligodendrocytes were always noted around the injection site (see Fig. $5 C$ ), especially close to the corpus callosum, and occasionally in the cortex in which they were radially aligned (data not shown). GFP ${ }^{+}$cells with an 
astrocytic morphology were not observed. Therefore, the MGE cells that we grafted are primarily committed to an interneuronal lineage.

\section{MGE-derived cells exhibit molecular properties of cortical interneurons}

Recent studies suggest that MGE progenitors are the principal source of cortical GABAergic interneurons (Lavdas et al., 1999; Sussel et al., 1999; Anderson et al., 2001; Wichterle et al., 2001). Interneurons can be classified into several subtypes based on neurochemical markers, such as $\mathrm{Ca}^{2+}$-binding proteins (PV, calbindin, and CR), neuropeptides (e.g., SOM, NPY, cholecystokinin, and vasoactive intestinal polypeptide) (DeFelipe, 1993, 1997, 2002; Kubota et al., 1994; Gonchar and Burkhalter, 1997; Cobos et al., 2005), and recording their physiological properties (Cauli et al., 1997; Gupta et al., 2000; Butt et al., 2005). To evaluate the interneuronal phenotype and molecular characteristics of transplanted MGE-GFP cells, we performed a series of immunohistochemical studies 30 and 60 DAT. Double immunofluorescence revealed that $68.6 \pm 4.8 \%$ of cortical $\mathrm{GFP}^{+}$graft-derived cells express GABA (Fig. 3A, Table 1); a comparable level of $\mathrm{GFP}^{+}$cells were double labeled with an antibody against GAD67 ( 70\%; data not shown). Subsets of the GFP ${ }^{+}$ neurons express NPY, SOM, PV, and CR (Fig. 3D-O, Table 1), at expression levels and in a distribution similar to those of the host interneurons. MGE-derived cells were also immunopositive for these neurotransmitters and markers in the striatum and hippocampus (Fig. 4, Table 1). They were distributed in the same areas of the host brain that usually contain these types of interneurons. Approximately $98 \%$ of MGE-derived $\mathrm{GFP}^{+}$cells were immunopositive for the neuronal marker $\mathrm{NeuN}$, and only a very small fraction of $\mathrm{GFP}^{+}$cells colabeled with antibodies to glial fibrillary acidic protein (1 of 797 cells) (Fig. $5 A$ ), S100 $\beta$ (31 of 1373 cells) (Fig. $5 G$ ), or the neuronal glutamate transporter excitatory amino acid carrier-1 (30 of 1014 cells). The remainder of $\mathrm{GFP}^{+}$cells were primarily oligodendrocytes positive for Olig2 $(\sim 1.8 \%)$ (Fig. $5 F$ ), mainly located close to the injection site and in areas of the corpus callosum. Endothelial cells within blood vessels were also observed in the injection site. The presence of MGE-derived oligodendrocytes is consistent with recent findings (Nery et al., 2001; Kessaris et al., 2006). GFP ${ }^{+}$cells were immunonegative for antibodies to CaM kinase II $\alpha$, ChAT, and TH (Fig. $5 B, D, E$ ). These findings indicate that grafted cells did not differentiate into a significant population of astrocytes, pyramidal cells, and catecholaminergic or cholinergic neurons. quantitative analysis.
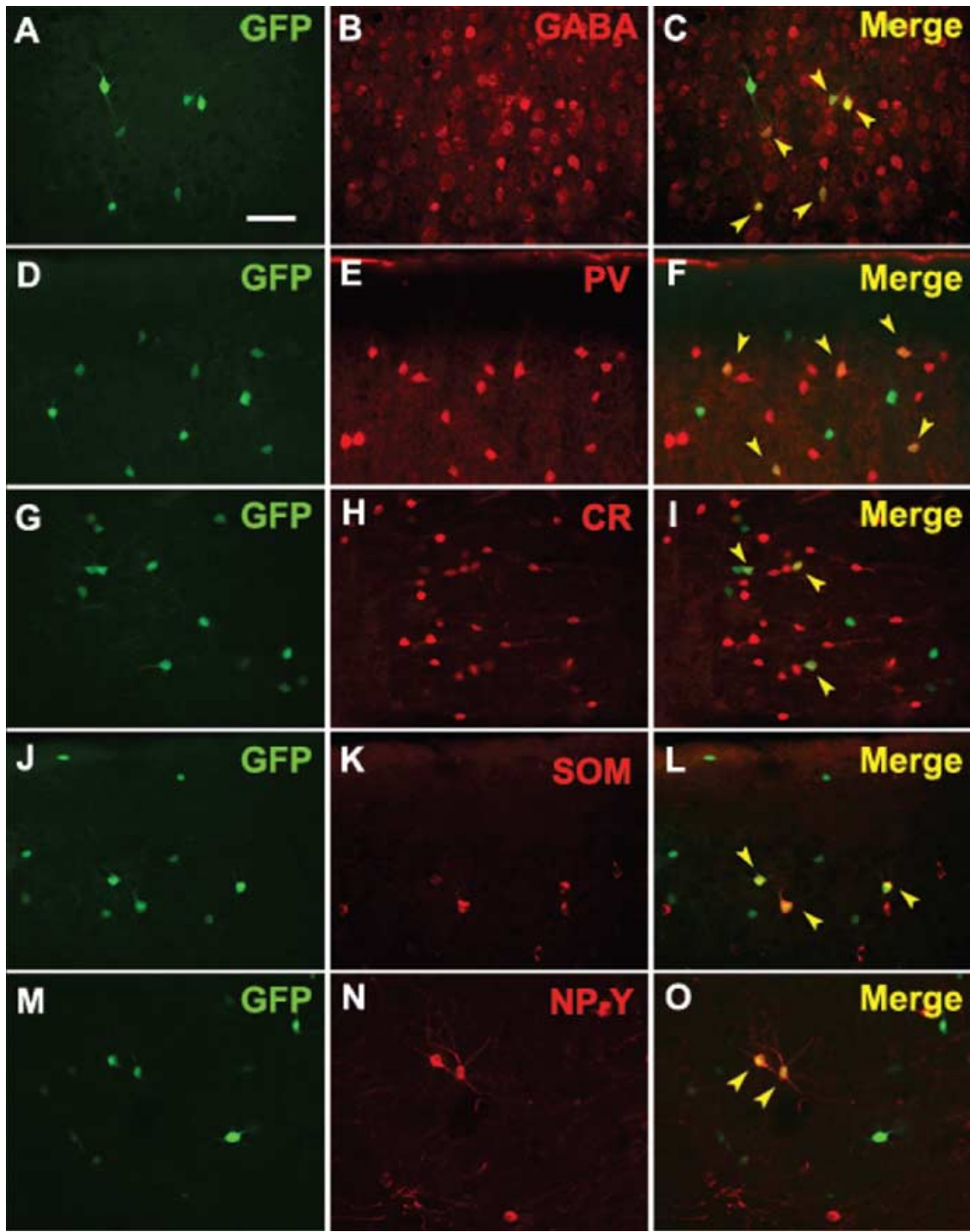

gure 3. Molecular characterization of MGE graft-derived cells in somatosensory $(A-F, J-O)$ and cingulate cortex $(G-I) 60$ DAT. Immunohistochemical colocalization of grafted GFP ${ }^{+}$cells with GABA, PV, CR, SOM, and NPY. Arrowheads show doublepositive cells for GFP and specific marker. Scale bar, $50 \mu \mathrm{m}$.

Table 1. MGE graft-derived interneuron subtypes $(n=5)$

\begin{tabular}{|c|c|c|c|c|c|}
\hline & GABA & PV & SOM & $C R$ & NPY \\
\hline Cortex & $68.6 \pm 4.8 \%$ & $38.3 \pm 5.4 \%$ & $\begin{array}{l}43.2 \pm 3.9 \% \\
53.1 \pm 5.3 \%^{a} \\
33.2 \pm 2.4 \%^{b}\end{array}$ & $\begin{array}{c}1.9 \pm 0.6 \% \\
10.3 \pm 1.3 \%^{c}\end{array}$ & $7.8 \pm 1.2 \%$ \\
\hline Striatum & $50.9 \pm 2.6 \%$ & $54.9 \pm 7.6 \%$ & $39.5 \pm 4.6 \%$ & $6.4 \pm 1.9 \%$ & $18.0 \pm 2.1 \%$ \\
\hline Hippo (DG) & $42.8 \pm 2.9 \%$ & $33.7 \pm 4.7 \%$ & $33.8 \pm 8.1 \%$ & $10.3 \pm 1.7 \%$ & $13.1 \pm 1.9 \%$ \\
\hline
\end{tabular}

Quantifications were performed in somatosensory cortex except for ${ }^{a}$ layers I-III of somatosensory cortex, ${ }^{b}$ layers IV-VI of somatosensory cortex, and ${ }^{c}$ retrosplenial cortex. DG, Dentate gyrus. All grafting experiments contained $\sim 50,000$ cells per injection. Two observers blinded to condition were used for

\section{MGE-derived cells exhibit interneuronal firing properties}

To assess whether MGE-derived cells had electrophysiological characteristics of cortical interneurons, $\mathrm{GFP}^{+}$cells were targeted for whole-cell current-clamp recording at 4 weeks after grafting (30 DAT). Diffusion of Alexa Red from the patch pipette permitted real-time confirmation of cellular recording site (Fig. $6 A$ ). If MGE cells mature into an interneuronal phenotype, they should exhibit little spike frequency adaptation, which is a hallmark electrical feature of GABAergic interneurons. In current-clamp re- 

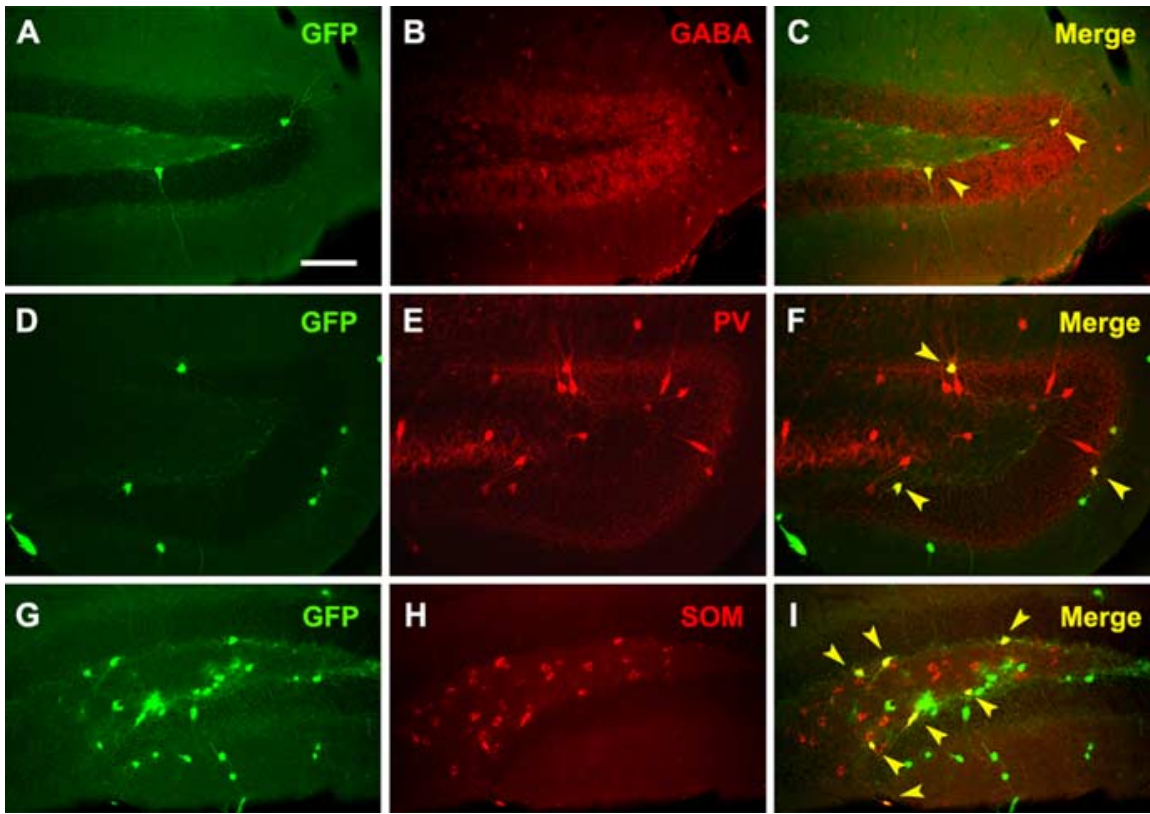

Figure 4. Grafted MGE-derived cells in the dentate gyrus of the hippocampus 60 DAT. Immunohistochemical colocalization of MGE-derived cells expressing GFP with GABA (A-C), PV (D-F), and SOM (G). Arrowheads show double-positive cells. Scale bar, $100 \mu \mathrm{m}$.
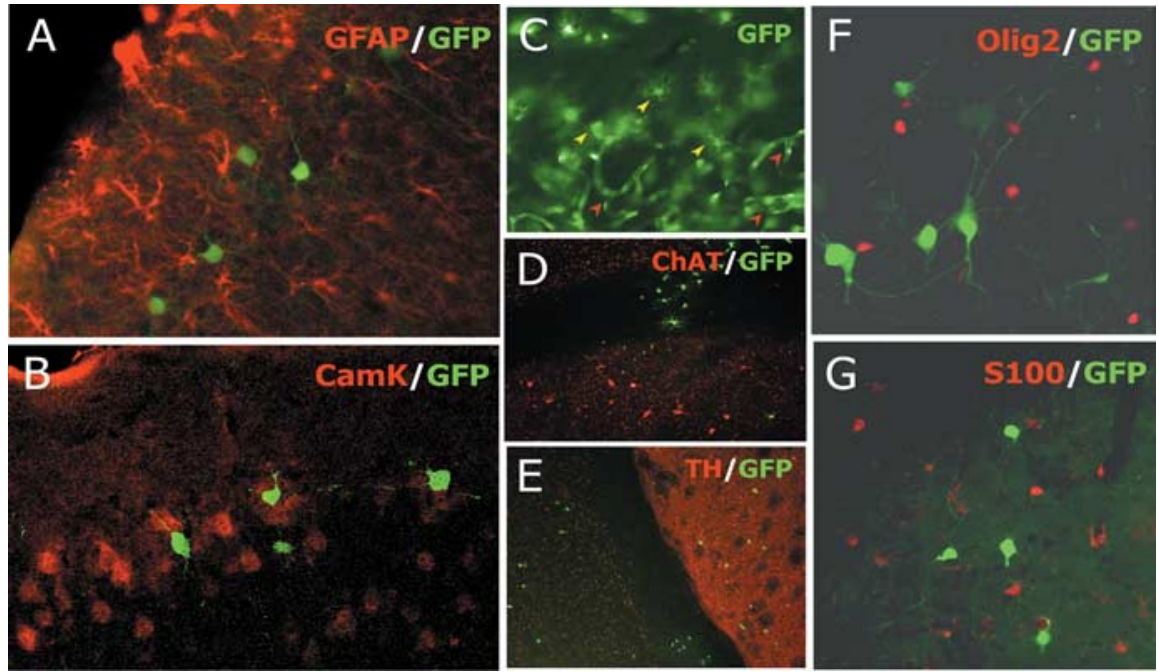

Figure 5. Double-immunohistochemical analysis of tissue obtained from grafted animals at 30 DAT failed to identify a significant population of non-neuronal GFP-expressing cells. Sample immunostaining panels are shown for NeuN $(\boldsymbol{A})$, glial fibrillary acidic protein (B, GFAP), CaM kinase $\| \alpha(\boldsymbol{C}$, CamK), ChAT (D), TH (E), 0lig2 (F), and $\mathbf{S 1 0 0} \beta(\boldsymbol{G})$. Sections shown are at least $300 \mu \mathrm{m}$ from the graft injection site. Note the absence of double-labeled cells. Near the injection site, GFP-positive cells with oligodendrocyte morphology (yellow arrowheads) were observed near putative blood vessels (red arrowheads).

cordings from $15 \mathrm{GFP}^{+}$cells sampled in cortical layer V, we measured mean values of $-70.9 \pm 0.9 \mathrm{mV}$ for resting membrane potential (RMP) and 101.4 $\pm 4.1 \mathrm{M} \Omega$ for input resistance $\left(R_{\mathrm{IN}}\right)$. In $14 \mathrm{GFP}^{+}$cells, depolarizing current pulses elicited action potentials (3.0 $\pm 0.4 \mathrm{~ms}$ duration; $69.0 \pm 3.3 \mathrm{mV}$ amplitude), and hyperpolarizing current pulses evoked a small degree of "sag" current (Fig. $6 B$ ). These intrinsic membrane properties are in the expected range for "mature" non-accommodating cortical interneurons (Markram et al., 2004). Analysis of spike firing patterns during long-duration depolarizing pulses (500-1000 ms) clearly revealed interneuron subtypes: regular-spiking nonpyramidal $(n=7)$, fast spiking $(n=2)$, and burstonset $\operatorname{RSNP}(n=3)$. Two cells were not recorded using longer steps, and one cell did not exhibit active firing properties during step depolarizations but had an $\mathrm{RMP}$ of $-70 \mathrm{mV}$ and $R_{\mathrm{IN}}$ of $100 \mathrm{M} \Omega$. The high firing frequency typical of $\mathrm{GFP}^{+}$cells sampled is shown in Figure $6, B$ and $C$; frequency-current relationships were linear as reported previously for hippocampal interneurons (Fig. 6D) (Smith et al., 1995). At slightly depolarized potentials $(-50$ to $-60 \mathrm{mV})$, spontaneous spike activity was consistently observed in current-clamp recordings from $\mathrm{GFP}^{+}$interneurons (Fig. 6E).

\section{Transplanted MGE cells influence} synaptic function in the host animal

To determine whether transplanted MGE precursors functionally integrate in the host brain, a series of in vitro electrophysiological studies were performed. Regions of neocortex containing $\mathrm{GFP}^{+}$cells were identified under epifluorescence (Figs. $6 A, 7 A$ ), and pyramidal neurons in regions surrounded by $\mathrm{GFP}^{+}$cells were chosen for patch-clamp recording. Recorded cells were filled with Lucifer yellow for post hoc confirmation of cell location and identity (Fig. 6A). Brain slices were prepared at various time points after transplantation $(2,3$, and 4 weeks). Spontaneous IPSCs on pyramidal neurons (Fig. $7 B$ ) reflect activation of postsynaptic GABA receptors after action potential-dependent vesicular transmitter release; IPSCs were completely abolished by $10 \mu \mathrm{M} B \mathrm{BI}$, a $\mathrm{GABA}_{\mathrm{A}}$ receptor antagonist (Fig. 7D). If a significant number of transplanted MGE cells integrate into the host microcircuitry as new GABAergic interneurons, we would expect an increase in the overall level of GABA-evoked synaptic events onto native pyramidal neurons. Increments in GABA-, PV-, and SOM- expressing neurons were observed in the cortical hemisphere ipsilateral to the injection site when compared with contralateral hemisphere (Table 2). In concordance with these anatomical observations, there were significant increases in IPSC amplitude and frequency in ipsilateral cortical slices from transplanted animals 4 weeks after surgery, e.g., a time when interneurons with mature morphology were observed. Control cortical slices were obtained from sham-operated mice or from the contralateral cortex of transplanted mice (which lacked $\mathrm{GFP}^{+}$cells) (Fig. $7 \mathrm{~B}, \mathrm{C}$ ). In an additional control experiment, heat-shocked dead MGE cells were grafted into recipient mice. Values for spontaneous IPSC amplitude (15 $\pm 0.7 \mathrm{pA}, 2$ weeks; $16.5 \pm 0.9 \mathrm{pA}, 3$ weeks; $15.6 \pm$ $0.7 \mathrm{pA}, 4$ weeks), time constant of decay ( $6.5 \pm 0.7 \mathrm{~ms}, 2$ weeks; $6.0 \pm 0.3 \mathrm{~ms}, 3$ weeks; $6.6 \pm 0.7 \mathrm{~ms}, 4$ weeks $)$, and rise time ( $5.5 \pm$ 

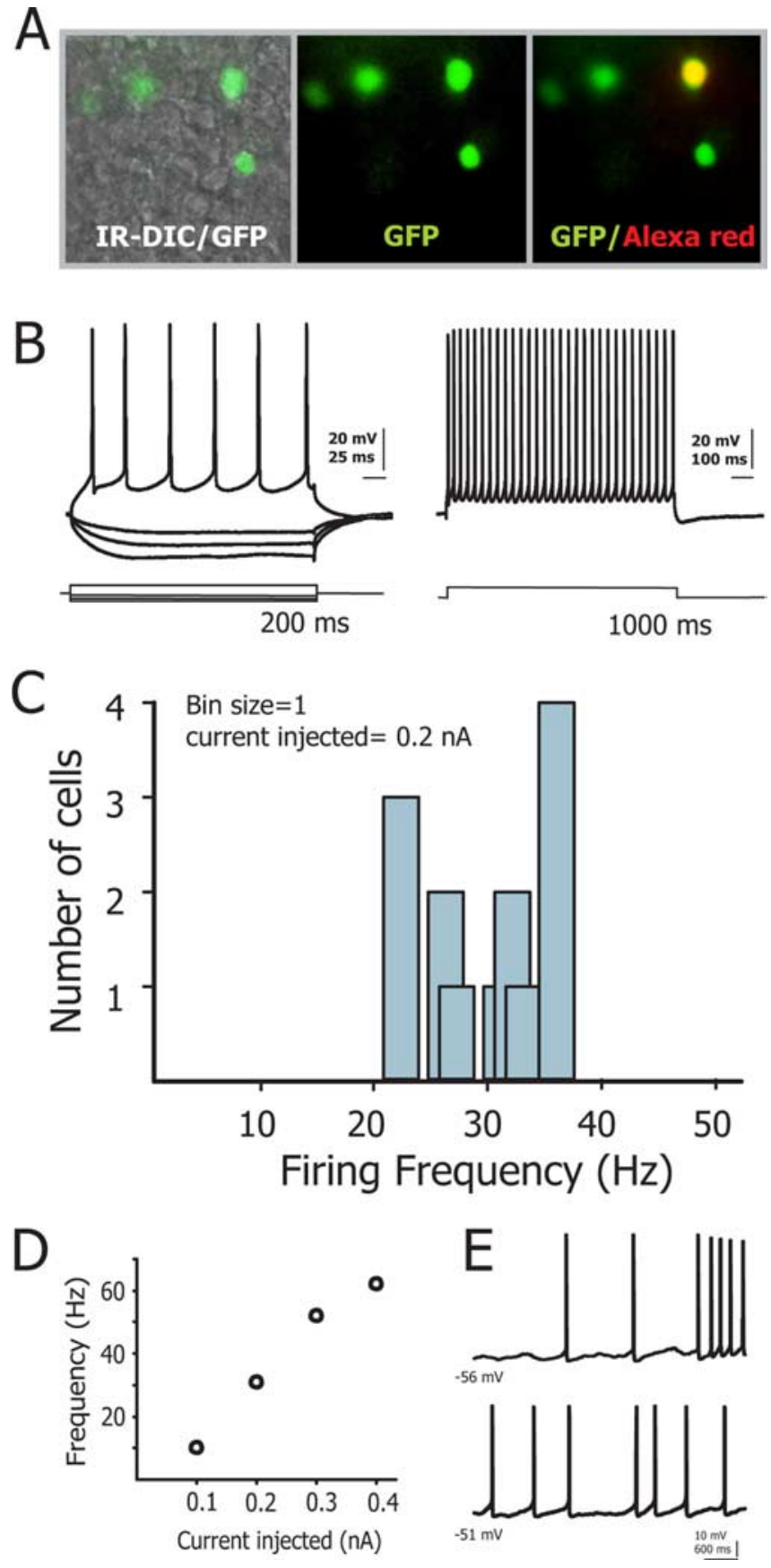

Figure 6. MGE-derived cells exhibit interneuronal firing properties. $\boldsymbol{A}$, IR-DIC image overlaid with an epifluorescence image of an acute coronal slice (4 weeks after grafting) containing $\mathrm{GFP}^{+}$MGE-derived cells; epifluorescence image at right of a cell filled with Alexa Red during the patch recording. $\boldsymbol{B}$, Membrane potential of the $\mathrm{GFP}^{+}$cell shown in $\boldsymbol{A}$ recorded under current clamp at the resting potential (approximately $-71 \mathrm{mV}$ ). Note the small degree of inward rectification with hyperpolarizing current steps $(200 \mathrm{~ms}$ ) and the lack of spike frequency adaptation with long depolarizing current steps (1000 ms) typical of mature cortical interneurons. This cell was classified as an RSNP interneuron. C, Graph of firing frequency of recorded GFP ${ }^{+}$ cells at depolarizing step of $0.2 \mathrm{nA}(n=14)$. $\boldsymbol{D}$, Plot of the linear frequency-current relationship for a typical GFP-positive interneuron. $\boldsymbol{E}$, Sample current-clamp traces from two different GFP-positive interneurons demonstrating spontaneous action potential firing in normal ACSF.

$0.7 \mathrm{~ms}, 2$ weeks; $5.0 \pm 0.4 \mathrm{~ms}, 3$ weeks; $1.4 \pm 0.2 \mathrm{~ms}, 4$ weeks) were similar to control data presented in Figure $7 C$.

A significant enhancement of GABAergic inhibition was not observed at 2 or 3 weeks after transplantation, not surprisingly, because histological analysis at these times showed an immature phenotype of grafted cells. Significant changes in IPSC rise time or decay time constant were not observed at any time point (Fig. $7 C$ ), suggesting that gross alterations in postsynaptic GABA subunit receptor expression do not occur in grafted animals. To further assess the potentially selective insertion of new inhibitory synapses in the host brain, we constructed event histograms for individual IPSC events. Similar to mean data presented above, no change in IPSC decay time or $10-90 \%$ rise time was noted (Fig. $7 G$ ). The amplitude distribution showed a clear shift toward larger values, which suggests an increase in the release of GABA from presynaptic sites in grafted animals (Fig. $7 G$ ) and is consistent with our anatomical observations of newly generated MGEderived interneurons. Because graft-derived $\mathrm{GFP}^{+}$cells were also observed in the hippocampal formation (Figs. 2, 3), we performed additional electrophysiological analysis of CA3 pyramidal neurons. Similar to cortical slices, IPSC frequency and amplitude were also increased in the hippocampus of grafted animals at 4 weeks after transplantation (Fig. 8). Values for CA3 control pyramidal cell frequency $(3.1 \pm 0.4 \mathrm{~Hz})$ and amplitude $(16.9 \pm$ $0.9 \mathrm{pA} ; n=10)$ were significantly greater than those from agematched grafted animals (frequency, $4.3 \pm 02 \mathrm{~Hz}, p<0.05$; amplitude, $23.6 \pm 1.4 \mathrm{pA} ; p<0.05 ; n=10)$. Consistent with an increase in the number of GABA-producing neurons, when action potential firing was blocked with tetrodotoxin, miniature IPSC frequencies were also increased in neocortical and hippocampal pyramidal cells 4 weeks after transplantation (cortex, $2.3 \pm 0.1 \mathrm{~Hz}, n=4 ; \mathrm{CA} 1,2.4 \pm 0.2 \mathrm{~Hz}, n=3$ ) when compared with controls (cortex, $1.3 \pm 0.2 \mathrm{~Hz}, n=4$; CA1, $1.1 \pm 0.1 \mathrm{~Hz}, n=$ 3 ; $p<0.05)$. These data demonstrate the potential for MGEderived precursors to modify circuit function in brain regions critical to cognition (Smith 1995; Amodio and Frith, 2006), epileptogenesis (Prince and Connors, 1984; Prince, 1985), and memory consolidation (Bosshardt et al., 2005).

To assess the overall level of inhibitory tone in grafted animals, we performed two additional analyses of spontaneous IPSCs. First, measurement of the total charge transfer (corresponding to total area under the IPSC current over a specified time period) indicated that synaptic inhibition was significantly increased in slices containing $\mathrm{GFP}^{+}$cells compared with age-matched controls (Figs. 7E, 8B). Second, consistent with an enhancement of GABAergic tone, there was a significant increase in the frequency of spontaneous IPSCs plotted as a cumulative distribution (Figs. 7F, 8C).

To test whether transplanted MGE cells synapse onto existing interneurons, and thereby modify cortical excitation (through inhibition of interneuron function), EPSCs were recorded from pyramidal neurons (holding potential of $-75 \mathrm{mV}$ ) in regions containing $\mathrm{GFP}^{+}$cells; spontaneous EPSCs were abolished by application of CNQX and APV, confirming a role for postsynaptic glutamate receptors (Fig. 9B). In comparing spontaneous EPSCs recorded on pyramidal cells from MGE-transplanted animals $(n=6)$ and controls $(n=6)$, no difference in amplitude, decay time constant, rise time, or frequency was noted (Fig. 9A). These findings suggest that overall excitatory tone in the host brain is not grossly altered after grafting of MGE precursors. To address whether transplanted neurons receive excitatory synaptic contact from host axons, we next examined spontaneous and evoked EPSCs onto $\mathrm{GFP}^{+}$neurons. $\mathrm{GFP}^{+}$cells exhibited spontaneous EPSCs that were blocked by CNQX and APV $(n=4)$ (Fig. 9B) and evoked EPSCs with a reversal potential near $0 \mathrm{mV}$ (Fig. 9C). EPSCs exhibited kinetics similar to those expected for "normal" glutamate-mediated synaptic currents. Together, these data suggest that MGE-derived GFP ${ }^{+}$cells function as inhibitory 

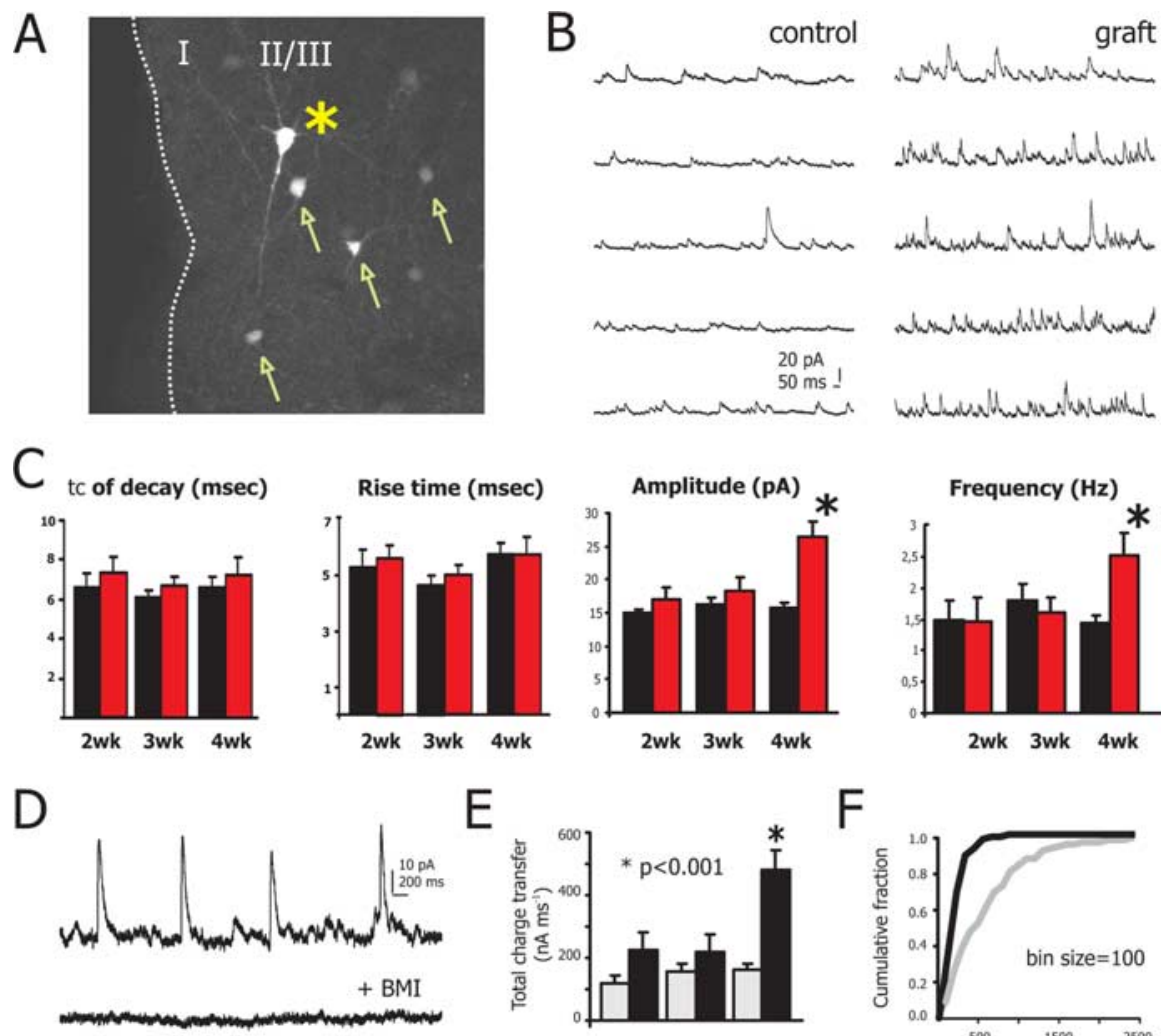

E

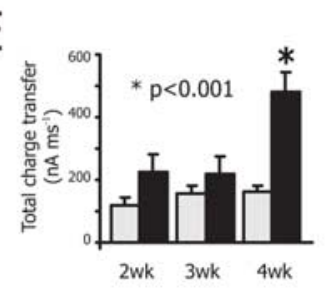

$F$

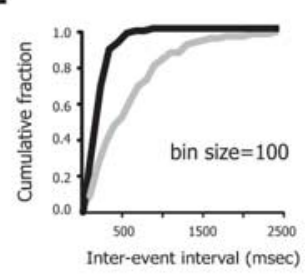

G
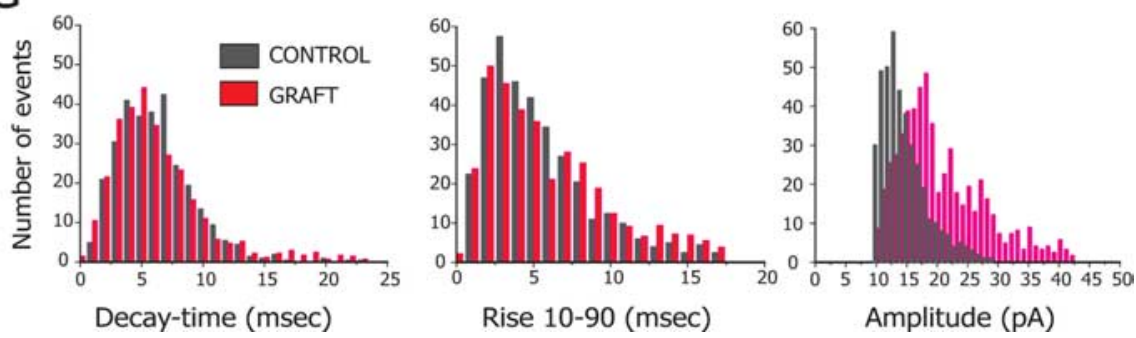

Figure 7. MGE-grafted cells alter synaptic function in the host brain. $\boldsymbol{A}$, Recording configuration for analysis of inhibitory current in the host brain. Panel shows the acute coronal slice with GFP ${ }^{+}$cells in layers I-III visualized under IR-DIC and epifluorescence microscope. A recording was obtained from a pyramidal neuron (yellow asterisk; cell filled with Lucifer yellow) in the vicinity of GFP ${ }^{+}$cells (green arrows). B, Sample traces of spontaneous IPSCs recorded from pyramidal cells (control brain and graft host brain) 4 weeks after grafting. Note the increase in IPSC amplitude and frequency for grafted animals versus age-matched controls. C, Cumulative data plots for all IPSC recordings from control (black bars) and grafted (red bars) animals are shown. Recordings were made at 2, 3, and 4 weeks after grafting. Data represent $7-10$ cells for each bar; data are presented as mean \pm SEM, and significance is taken as $p<0.05$ using one-way ANOVA. D , Sample IPSC traces before and after application of the GABA receptor antagonist bicuculline (10 $\mu \mathrm{M} B \mathrm{BM})$. $\boldsymbol{E}$, Measurement of the total charge transfer for pyramidal cells from control (gray bars) and grafted (black bars) brain. Note the significant increase for grafted brains at 4 weeks. $\boldsymbol{F}$, Cumulative probability plot of spontaneous IPSC interevent intervals shows higher frequency values for grafted brains $(p<0.05)$. G, Distribution histograms for IPSC decay time (left), 10-90\% rise time (middle), and amplitude (right). Note the shift to larger amplitude IPSC events for pyramidal cells from grafted animals.

Table 2. Interneuron increment in transplanted somatosensory cortex

\begin{tabular}{lll}
\hline & Cortex $^{a}$ & Cortex $^{b}$ \\
& $(100 \mu \mathrm{m})$ & $(1200 \mu \mathrm{M})$ \\
\hline GABA & $12.1 \pm 3.7 \%(p<0.01)$ & $8.4 \pm 3.5(p<0.01)$ \\
PV & $9.8 \pm 2.1 \%(p<0.01)$ & $4.8 \pm 3.6 \%(p=0.23)$ \\
SOM (I-III) & $16.1 \pm 2.8 \%(p<0.01)$ & $12.9 \pm 3.6 \%(p<0.05)$ \\
\hline
\end{tabular}

Contralateral results were taken as $100 \%$.

${ }^{a}$ Estimation of cell increment $100 \mu \mathrm{m}$ around the injection site. Quantification was performed in two slices $50 \mu \mathrm{M}$ forward and backward from the injection site.

${ }^{b}$ Estimation of cell increment $1200 \mu \mathrm{m}$ around the injection site. Quantification was performed in three slices forward plus three slices backward from the injection site. Significance $(p)$ was estimated with a Student's $t$ test. $n=10$. All grafting experiments contained $\sim 50,000$ cells per injection. Two observers blinded to condition were used for quantitative analysis. interneurons receiving excitatory input from local pyramidal neurons and integrating into cortical synaptic circuitry of the host brain in such a manner as to modify the overall level of inhibition.

\section{Discussion}

Transplantation of neuronal precursors is a promising therapeutic strategy for brain repair. Ideally, grafted cells should be able to disperse through the affected area and differentiate into neurons that contribute to restoration (or modulation) of existing neural circuit deficits. Here we investigated whether inhibition could be modified by transplantation of progenitor cells that differentiate into GABAergic interneurons. We demonstrate that MGEderived neuronal precursors grafted into the early postnatal brain are capable of long-distance dispersion across the neocortex, hippocampus, and other areas of the juvenile brain. These cells then acquire morphological, molecular, and physiological characteristics of mature GABAergic interneurons. Finally, these grafted MGEderived cells functionally integrate and alter inhibitory tone in the host brain.

Thus, the present study demonstrates that MGE precursors could be used to modify synaptic circuits in a postnatal brain. ES-derived cells or other neural precursors transplanted into postnatal brain do not migrate extensively but form clumps of graft-derived cells in, or near, the site of transplantation (Bosch et al., 2004; Ruschenschmidt et al., 2005; Thompson, 2005). With the latter treatments, multiple graft sites are required, resulting in a limited volume of host brain being modified and a spotty distribution of the intended physiological effects. In contrast, MGE precursors possess an extraordinary potential to migrate in adult brain, dispersing $\sim 1.5 \mathrm{~mm}$ away from the graft site (Wichterle et al., 1999). Here we demonstrate an even greater ability of these cells to disperse when transplanted into the neonatal brain, reaching maximum migration distances of $5 \mathrm{~mm} 2$ months after transplantation. As such, a single injection of MGE precursors could influence a relatively wide area of the host brain, an important aspect when considering the potential clinical usefulness of transplanted cells.

GABAergic interneurons play a key role in establishing a balance between excitation and inhibition in the developing and adult brain. Therefore, MGE cells may be ideally suited to experimentally modify this balance or therapeutically reestablish this equilibrium. Not only do MGE cells disperse widely, but they also efficiently differentiate into local inhibitory interneurons when grafted into postnatal brain. The present results show that $>65 \%$ of MGE-derived cells express GABA. Grafted cells also contain SOM and NPY, neuropeptides 


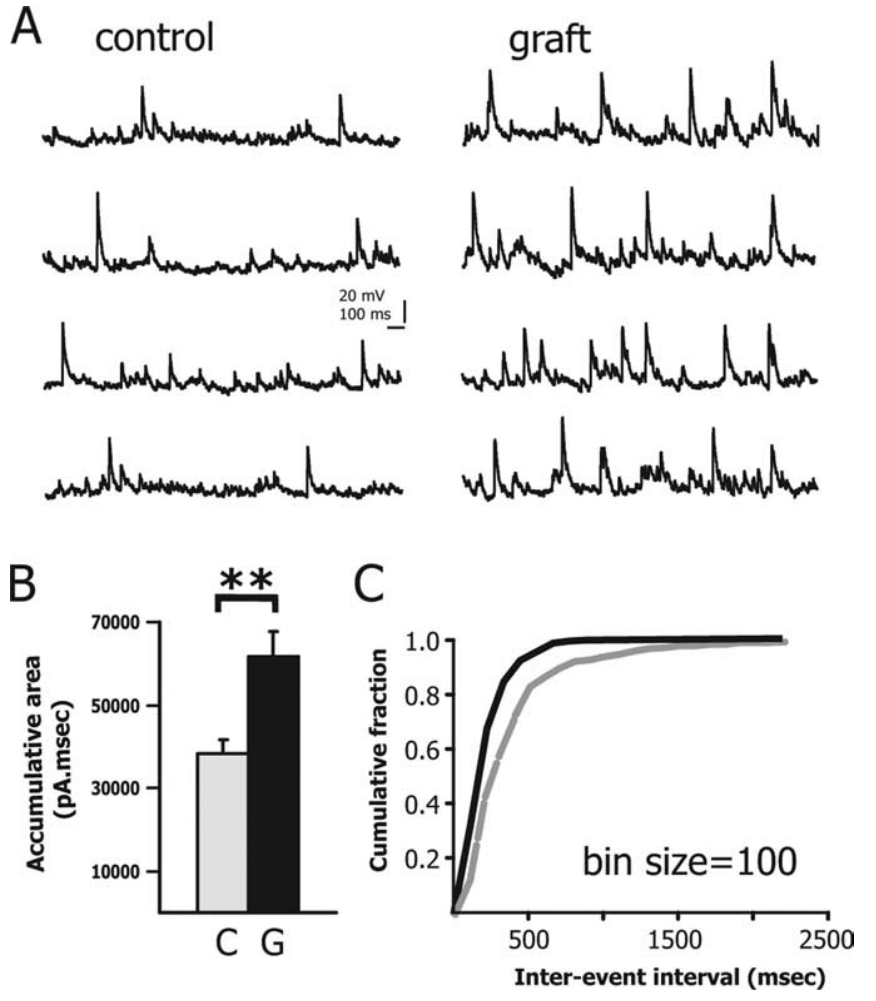

Figure 8. Synaptic inhibitory current is increased in the hippocampus from grafted mice. $\boldsymbol{A}$, Spontaneous IPSCS of hippocampal pyramidal cells from control grafted mice. $\boldsymbol{B}$, Measurement of the total charge transfer of IPSCs recorded from CA1 hippocampal pyramidal cells from control (C) and grafted (G) brain. Note the significant increase values for grafted brains at 4 weeks. C, Cumulative probability plots of spontaneous IPSC interevent intervals shown higher frequency values for grafted brains $(p<0.05)$. Error bars indicate SEM. ${ }^{* *} p<0.001$ by ANOVA.

normally colocalized in subtypes of mature cortical interneurons (DeFelipe, 1993, 1997; Kubota et al., 1994; Gonchar and Burkhalter, 1997) and capable of acting as endogenous anticonvulsant agents (Baraban et al., 1995; Mazarati and Wasterlain, 2002; Saar et al., 2002). We did not detect significant numbers of pyramidal-like neurons or astrocytes that were derived from transplanted MGE cells. This contrasts with ES-derived cell transplants, which exhibit heterogeneous morphological and immunohistochemical phenotypes in the host brain. Although $\sim 14 \%$ of ES-derived cells grafted into the postnatal brain express GAD67 (a marker of GABA-containing interneurons), another $44 \%$ exhibit a glutamatergic phenotype, and an unknown number are presumably astrocytes (Wernig et al., 2004). Perhaps most importantly, tumors were never observed in our MGE-grafted mice, although this is a common problem when ES-derived progenitors are used for transplantation (Wernig et al., 2004; Ruschenschmidt et al., 2005).

Single-cell recordings from transplanted ES or RN33B cells have been reported in the literature (Englund et al., 2002; Wernig et al., 2004). In each case, evidence that transplanted cells exhibit active firing properties was presented. Here we show direct evidence that transplanted MGE-derived cells sampled in layer V exhibit an "electrical fingerprint" typical of mature GABA-containing interneurons. For example, MGE-GFP cells consistently fired at a high frequency and exhibited very little accommodation. These firing properties are consistent with a classification as non-accommodating basket-cell interneurons. It is likely that additional current-clamp sampling of $\mathrm{GFP}^{+}$cells across other layers of grafted cortex will uncover additional interneuron subtypes as was observed in a recent analysis of MGE precursors grafted in utero and analyzed between postnatal

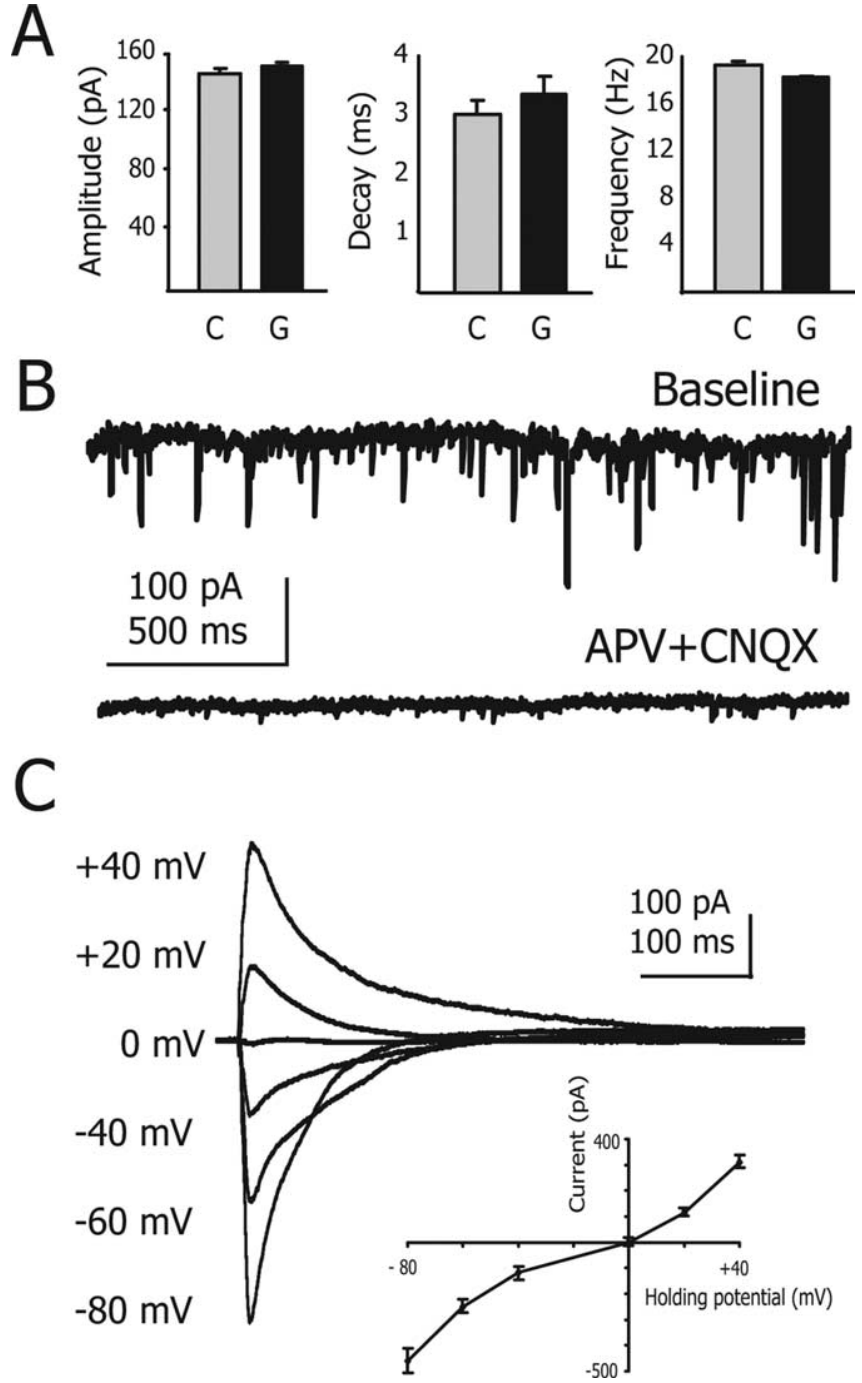

Figure 9. Glutamatergic synaptic excitation is not altered in neocortex and MGE grafted mice. $\boldsymbol{A}$, Plots of all cortical pyramidal cells sampled for spontaneous EPSC data. Spontaneous EPSC amplitude, decay time, and frequency show no significant difference between controls ( $C$, light gray bars) and grafted (G, black bars) brains. $\boldsymbol{B}$, Representative traces of spontaneous EPSCs recorded from a GFP ${ }^{+}$ grafted cell at 4 weeks after grafting. Spontaneous EPSCS were abolished by application of CNQX and APV (bottom trace). C, Sample of evoked EPSC recording from GFP ${ }^{+}$grafted cells at different holding potentials showing the reversal membrane potential at $0 \mathrm{mV}$ (see inset graph).

days 13 and 22 (Butt et al., 2005). Our results confirm that MGE cells generate cortical interneurons (Anderson et al., 2001; Xu et al., 2004; Butt et al., 2005) and extend these observations to demonstrate their functional integration into cortical and hippocampal networks. In previous analysis of functional integration, single-cell recordings focused exclusively on demonstrations that transplanted cells receive excitatory and/or inhibitory synaptic input. Here we also demonstrate that transplanted MGE-derived cells receive excitatory synaptic input (Fig. 9). Moreover, we present evidence that grafted progenitor cells send inhibitory outputs, which impact existing pyramidal neurons (Figs. 7, 8). Notably, we found that pyramidal cells in regions containing MGE-derived cells exhibit an increased number of GABA-mediated synaptic events and that GABAergic tone is significantly enhanced in these regions of the host brain. Importantly, altered inhibition was not observed in control animals receiving dead progenitors or in contralateral brain regions lacking GFP-positive neurons. Because MGE-derived cells did not alter excitatory cortical circuitry or differentiate to neurons with a 
pyramidal-cell morphology, these findings suggest a method for enhancement of inhibitory systems.

Our demonstration that grafted progenitor cells produce functionally integrated GABAergic neurons, even in the presence of endogenous GABAergic neurons, after embryonic stages of neurodevelopment are complete, and in a wide variety of brain regions, suggests that MGE-derived cells could be useful in neurological conditions in which increased inhibition would be beneficial, e.g., epilepsy or schizophrenia. MGE precursors may also be used to correct levels of activity in deafferented brain regions such as in Parkinson's disease or, in conjunction with their inhibitory function, may be used as cellular vectors to deliver therapeutic molecules to wide regions of the brain.

\section{References}

Amodio DM, Frith CD (2006) Meeting of the minds: the medial frontal cortex and social cognition. Nat Rev Neurosci 7:268-277.

Anderson SA, Eisenstat DD, Shi L, Rubenstein JL (1997) Interneuron migration from basal forebrain to neocortex: dependence on Dlx genes. Science 278:474-476.

Anderson SA, Marin O, Horn C, Jennings K, Rubenstein JL (2001) Distinct cortical migrations from the medial and lateral ganglionic eminences. Development 128:353-363.

Anderson SA, Kaznowski CE, Horn C, Rubenstein JL, McConnell SK (2002) Distinct origins of neocortical projection neurons and interneurons in vivo. J Neurosci 12:702-709.

Baraban SC, Hollopeter G, Erickson JC, Schwartzkroin PA, Palmiter RD (1995) Knock-out mice reveal a critical antiepileptic role for neuropeptide Y. J Neurosci 17:8927-8936.

Bjorklund A, Lindvall O (2000) Cell replacement therapies for central nervous system disorders. Nat Neurosci 3:537-544.

Bosshardt S, Schmidt CF, Jaermann T, Degonda N, Boesiger P, Nitsch RM, Hock C, Henke K (2005) Effects of memory consolidation on human hippocampal activity during retrieval. Cortex 41:486-498.

Bosch M, Pineda JR, Sunol C, Petriz J, Cattaneo E, Alberch J, Canals JM (2004) Induction of GABAergic phenotype in a neural stem cell line for transplantation in an excitotoxic model of Huntington's disease. Exp Neurol 190:42-58.

Butt SJ, Fuccillo M, Nery S, Noctor S, Kriegstein A, Corbin JG, Fishell G (2005) The temporal and spatial origins of cortical interneurons predict their physiological subtype. Neuron 48:524-527.

Calcagnotto ME, Paredes MF, Baraban SC (2002) Heterotopic neurons with altered inhibitory synaptic function in an animal model of malformationassociated epilepsy. J Neurosci 22:7596-7605.

Cauli B, Audinat E, Lambolez B, Angulo MC, Ropert N, Tsuzuki K, Hestrin S, Rossier J (1997) Molecular and physiological diversity of cortical nonpyramidal cells. J Neurosci 17:3894-3906.

Cobos I, Calcagnotto ME, Vilaythong AJ, Thwin MT, Noebels JL, Baraban SC, Rubenstein JL (2005) Mice lacking DLX1 show subtype-specific loss of interneurons, reduced inhibition and epilepsy. Nat Neurosci 8:1059-1068.

DeFelipe J (1993) Neocortical neuronal diversity: chemical heterogeneity revealed by colocalization studies of classic neurotransmitters, neuropeptides, calcium-binding proteins, and cell surface molecules. Cereb Cortex 3:273-289.

DeFelipe J (1997) Types of neurons, synaptic connections and chemical characteristics of cells immunoreactive for calbindin-D28K, parvalbumin and calretinin in the neocortex. J Chem Neuroanat 14:1-19.

DeFelipe J (2002) Cortical interneurons: from Cajal to 2001. Prog Brain Res $136: 215-238$

Emsley JG, Mitchell BD, Magavi SS, Arlotta P, Macklis JD (2004) The repair of complex neuronal circuitry by transplanted and endogenous precursors. NeuroRx 1:452-471.

Englund U, Bjorklund A, Wictorin K, Lindvall O, Kokaia M (2002) Grafted neural stem cells develop into functional pyramidal neurons and integrate into host cortical circuitry. Proc Natl Acad Sci USA 99:17089-17094.

Gonchar Y, Burkhalter A (1997) Three distinct families of GABAergic neurons in rat visual cortex. Cereb Cortex 7:347-358.

Gupta A, Wang Y, Markram H (2000) Organizing principles for a diversity of GABAergic interneurons and synapses in the neocortex. Science 287:273-278
Hadjantonakis AK, Gertsenstein M, Ikawa M, Okabe M, Nagy A (1998) Generating green fluorescent mice by germline transmission of green fluorescent ES cells. Mech Dev 76:79-90.

Kessaris N, Fogarty M, Iannerelli P, Grist M, Wegner M, Richardson WD (2006) Competing waves of oligodendrocytes in the forebrain and postnatal elimination of an embryonic lineage. Nat Neurosci 9:173-179.

Kubota Y, Hattori R, Yui Y (1994) Three distinct subpopulations of GABAergic neurons in rat frontal agranular cortex. Brain Res 649:159-173.

Lavdas AA, Grigoriou M, Pachnis V, Parnavelas JG (1999) The medial ganglionic eminence gives rise to a population of early neurons in the developing cerebral cortex. J Neurosci 19:7881-7888.

Lois C, Alvarez-Buylla A (1994) Long-distance neuronal migration in the adult mammalian brain. Science 264:1145-1148.

Marin O, Rubenstein JL (2001) A long, remarkable journey: tangential migration in the telencephalon. Nat Rev Neurosci 2:780-790.

Marin O, Rubenstein JL (2003) Cell migration in the forebrain. Annu Rev Neurosci 26:441-483.

Markram H, Toledo-Rodriguez M, Wang Y, Gupta A, Silberberg G, Wu C (2004) Interneurons of the neocortical inhibitory system. Nat Rev Neurosci 5:793-807.

Mazarati A, Wasterlain CG (2002) Anticonvulsant effects of four neuropeptides in the rat hippocampus during self-sustaining status epilepticus. Neurosci Lett 331:123-127.

Nery S, Wichterle H, Fishell G (2001) Sonic hedgehog contributes to oligodendrocyte specification in the mammalian brain. Development 128:527-540.

Paxinos G, Watson C (1998) The rat brain in stereotaxic coordinates. New York: Academic.

Prince DA (1985) Physiological mechanisms of focal epileptogenesis. Epilepsia 26 [Suppl 1]:S3-S14.

Prince DA, Connors BW (1984) Mechanisms of epileptogenesis in cortical structures. Ann Neurol 16:S59-S64.

Ruschenschmidt C, Koch PG, Brustle O, Beck H (2005) Functional properties of ES cell-derived neurons engrafted into the hippocampus of adult normal and chronically epileptic rats. Epilepsia 46 [Suppl 5]:174-183.

Saar K, Mazarati AM, Mahlapuu R, Hallnemo G, Soomets U, Kilk K, Hellberg S, Pooga M, Tolf BR, Shi TS, Hokfelt T, Wasterlain C, Bartfai T, Langel U (2002) Anticonvulsant activity of a nonpeptide galanin receptor agonist. Proc Natl Acad Sci USA 99:7136-7141.

Smith AD (1995) Hippocampal atrophy and cognitive impairment. Lancet 345:992.

Smith KL, Szarowski DH, Turner JN, Swann JW (1995) Diverse neuronal populations mediate local circuit excitation in area CA3 of developing hippocampus. J Neurophysiol 74:650-672.

Sussel L, Marin O, Kimura S, Rubenstein JL (1999) Loss of Nkx2.1 homeobox gene function results in a ventral to dorsal molecular respecification within the basal telencephalon: evidence for a transformation of the pallidum into the striatum. Development 126:3359-3370.

Thompson KW (2005) Genetically engineered cells with regulatable GABA production can affect afterdischarges and behavioral seizures after transplantation into the dentate gyrus. Neuroscience 133:1029-1037.

Wernig M, Benninger F, Schmandt T, Rade M, Tucker KL, Bussow H, Beck H, Brustle O (2004) Functional integration of embryonic stem cell-derived neurons in vivo. J Neurosci 24:5258-5268.

Wichterle H, Garcia-Verdugo JM, Herrera DG, Alvarez-Buylla A (1999) Young neurons from medial ganglionic eminence disperse in adult and embryonic brain. Nat Neurosci 2:461-466.

Wichterle H, Turnbull DH, Nery S, Fishell G, Alvarez-Buylla A (2001) In utero fate mapping reveals distinct migratory pathways and fates of neurons born in the mammalian basal forebrain. Development 128:3759-3771.

Wichterle H, Alvarez-Dolado M, Erskine L, Alvarez-Buylla A (2003) Permissive corridor and diffusible gradients direct medial ganglionic eminence cell migration to the neocortex. Proc Natl Acad Sci USA 100:727-732.

Winkler C, Kirik D, Bjorklund A (2005) Cell transplantation in Parkinson's disease: how can we make it work? Trends Neurosci 28:86-92.

Wonders C, Anderson SA (2005) Cortical interneurons and their origins. The Neuroscientist 11:199-205.

Xu Q, Cobos I, De La Cruz E, Rubenstein JL, Anderson SA (2004) Origins of cortical interneuron subtypes. J Neurosci 24:2612-2622. 